\title{
MODEL KOMUNIKASI PEMERINTAHAN KOTA TANJUNG PINANG DALAM PENGEMBANGAN WISATA PULAU PENYENGAT KEPULAUAN RIAU
}

\author{
Ismandianto $^{1}$, Syafri Harto ${ }^{2}$, dan Tito Handoko ${ }^{3}$ \\ ${ }^{1}$ Jurusan Ilmu Komunikasi Fakultas Ilmu Sosial dan Ilmu Politik Universitas Riau \\ ${ }^{2}$ Jurusan Hubungan Internasional Fakultas Ilmu Sosial dan Ilmu Politik Universitas Riau \\ ${ }^{3}$ Jurusan Ilmu Pemerintahan Fakultas Ilmu Sosial dan Ilmu Politik Universitas Riau \\ ismandianto@lecturer.unri.ac.id
}

\begin{abstract}
ABSTRAK
Kawasan Pulau Penyengat merupakan destinasi wisata yang memiliki karakteristik khusus di indonesia, namun dalam pengelolaannya masih menghadapi banyak kendala seperti kurangnya keterlibatan masyarakat dalam pengelolaan sumber daya pariwisata yang ada dan rendahnya kualitas sarana dan prasarana Pariwisata. Pengembangan kawasan Pulau Penyengat sebagai kawasan wisata unggulan juga terbentur pada berbagai regulasi, komunikasi pemerintahan antar pemerintahan dengan belum maksimal meskipun objek wisata pulau penyengat sudah ditetapkan sebagai cagar budaya nasional. Pemeliharaan objek wisata dilakukan oleh Balai Arkeologi yang unit teknisnya berada di Batu Sangkar Sumatera Barat, dampaknya komunikasi pemerintahan daerah terutama dalam hal alokasi anggaran Pemerintah kota penyengat tidak dapat dilakukan baik. Penelitian ini bertujuan untuk (1) mengidentifikasi model komunikasi pemerintahan dalam pengelolaan potensi objek wisata di Pulau Penyengat, (2) mengkaji karakteristik masyarakat sehingga terlihat bentuk dan tingkat partisipasi masyarakat dalam pemeliharaan dan pelestarian lingkungan hidup dalam mendukung Wisata di Pulau Penyengat, Penelitian ini dilaksanakan di Pulau Penyengat Kota Tanjungpinang Provinsi Kepulauan Riau. Data diperoleh dengan menggunakan metode survey dengan pendekatan kualitatif, pengamatan dan pengukuran lapangan, wawancara dan dokumentasi. Analisis data dilakukan dengan teknik analisis deskriptif, dan diperkuat dengan analisis SWOT. Hasil penelitian menunjukkan partisipasi masyarakat dalam pengembangan wisata Pulau Penyengat belum maksimal. Dan berdasarkan analisis dikembangkan komunikasi pemerintahan merupakan faktor penting dalam pengembangan desa wisata pulau penyengat.
\end{abstract}

\section{Kata Kunci: Komunikasi, Pengembangan dan Pariwisata Pulau Penyengat}

\section{PENDAHULUAN}

Pengembangan destinasi pariwisata masih mengalami sejumlah kendala dan hambatan, baik dari komunikasi pemerintah mapun manajemen produk wisata yang dikembangkan. Di sisi lain, perkembangan pariwisata dunia dan trend pasar semakin menuntut pengelolaan destinasi pariwisata untuk mampu memberikan daya tarik optimal, pelayanan yang prima dan berkualitas serta berbagai kemudahan dari segi akses informasi, trasportasi, aksesibilitas maupun kemudahan dan kenyamanan berwisata 
NAKHODA:

JURNAL

ILMU PEMERINTAHAN
NAKHODA: JURNAL ILMU PEMERINTAHAN

Edisi Januari - Juni 2019 Volume: 18 Nomor: 1

ISSN : 1829-5827 | E-ISSN : 2656-5277

DOI : https://doi.org/10.35967/jipn

https://nakhoda.ejournal.unri.ac.id/index.php/JIPN lainnya di Indonesia.

Dinamika perkembangan pariwisata nasional sangat terlihat dari implikasi sektor ekonomi dan sosial serta kesejahteraan masyarakat. Kegiatan pariwisata akan berakibat timbulnya kebutuhan akan barang dan jasa yang selanjutnya akan merangsang pertumbuhan produksi domestik. Kemajuan perkembangan objek wisata memiliki keterkaitan lintas sektor ekonimi, sosial dan budaya yang mampu membuka peluang investasi yang sangat luas misalnya industri perhotelan dan industri kreatif lainnya maupun jasa.

Kawasan Pulau Penyengat memiliki karakteristik tersendiri seperti lokasinya yang terpisah, adat istiadat masyarakatnya yang masih dipegang teguh, warisan pusaka (heritage) yang telah berusia ratusan tahun dan cerita-cerita masyarakat serta peninggalan lainnya yang mendorong keingintahuan orang terhadap Pulau Penyengat. Semakin meningkatnya jumlah kunjungan wisatawan menandakan bahwa kawasan Pulau Penyengat memiliki karakteristik yang memikat dan menjadi perhatian banyak orang. Akan tetapi daya pikat wisatawan tersebut nyatanya belum didukung oleh ketersediaan informasi dan akomodasi sehingga kawasan wisata Pulau Penyengat belum berkembang sebagaimana kawasan wisata unggulan di Jawa, Bali, Nusatenggara dan Papua.

Sementara itu, Komunikasi pemerintahan mempunyai dampak baik terhadap tipe, sasaran, tugas pemerintah termasuk didalamnya pemeliharaan hubungan antar lembaga yang berkaitan dengan pariwisata, tanpa adanya sarana dan prasarana untuk hubungan komunikasi pemerintahan ke segala arah dalam suatu kegiatan akan sulit diketahui apa yang sudah dicapai tujuan, dan bagaimana kendala dalam pelaksanaan pekerjaan, sehingga sulit bagi organisasi untuk mengevaluasi pekerjaan. Karena komunikasi pemerintahan adalah sumber informasi bagi pimpinan atau eksekutif dalam membuat berbagai kebijakan.

Berdasarkan pemaparan itu, jelas bahwa upaya komunikasi pemerintahan Tanjung Pinang Kepulauan Riau dalam pengembangan kawasan wisata Pulau Penyengat masih belum optimal, aspekaspek sebagaimana penjelasan di atas secara empirik masih belum terpenuhi. Selain itu, pengembangan kawasan wisata Pulau Penyengat belum menyentuh pada aspek man made sebagaimana dijabarkan dalam portofolio produk dalam kebijakan pengembangan destinasi pariwisata Indonesia 2016-2019.

Untuk menyampaikan pesan kepada masyarakat tidak lah mudah, pesan yang disampaikan tidak akan selalu efektif terkadang ada juga terjadi miss komunikasi, oleh karena itu sebuah pesan dapat dikemas dengan baik menggunakan model-model komunikasi. Model komunikasi menurut Sereno dan Mortensen merupakan deskripsi ideal mengenai apa yang dibutuhkan untuk terjadinya komunikasi, model komunikasi merepresentasikan secara abstrak ciri-ciri penting dalam menghilangkan rincian komunikasi yang tidak perlu dalam dunia nyata. Model komunikasi dapat membantu kita dalam menjelaskan teori dan menyarankan cara-cara untuk memperbaiki konsep- konsep sehingga pesan yang akan kita sampaikan nantinya bisa efektif (Mulyana, 2007: 132).

Sementara itu ditinjau dari aspek 
NAKHODA:

JURNAL

ILMU PEMERINTAHAN
NAKHODA: JURNAL ILMU PEMERINTAHAN

Edisi Januari - Juni 2019 Volume: 18 Nomor: 1

ISSN : 1829-5827 | E-ISSN : 2656-5277

DOI : https://doi.org/10.35967/jipn

https://nakhoda.ejournal.unri.ac.id/index.php/JIPN prioritas pintu kedatangan utama wisatawan mancanegara, Pulau Penyengat masuk dalam great Batam dengan total wisatawan mancanegara mencapai 1.885.012 orang (22\%) di bawah great Bali dan great Jakarta. Artinya bahwa, Great Batam tergolong sebagai pintu masuk kedatangan wisman yang cukup potensial. Namun demikian kawasan Tanjungpinang khusus Pulau Penyengat nyatanya tidak masuk dalam 50 Destinasi Pariwisata Nasional maupun 88 kawasan strategis pariwisata nasional.

Sejatinya daya dukung lingkungan (nature) Pulau Penyengat cukup baik untuk dikembangkan menjadi kawasan wisata berbasis lingkungan baik darat maupun lautnya, akan tetapi aspek ini belum dieksplorasi lebih lanjut oleh Pemerintah maupun pegiat pariwisata di Tanjungpinang.

Maka berdasarkan uraian tersebut di atas, studi ini dilakukan dengan alasanalasan objektif; bahwa kawasan Pulau Penyengat merupakan destinasi wisata yang memiliki karakteristik, namun dalam pengelolaannya masih menghadapi banyak kendala seperti kurangnya keterlibatan masyarakat dalam pengelolaan seumber daya pariwisata yang ada dan rendahnya kualitas sarana dan prasarana Pariwisata di Pulau Penyengat. Dan pengembangan kawasan wisata Pulau Penyengat terdapat persoalan status otonomi, bahwa Pulau Penyengat saat ini berstatus sebagai wilayah administratif Kelurahan sehingga inisiatif masyarakat Pulau Penyengat seringkali terbentur dengan kewenangan pengelolaan wilayah oleh Lurah.

Oleh sebab itu studi ini penelitian dibuat untuk melihat partisipasi komunikasi pemerintah dalam mengembangkan wisata pulau penyengat Propinsi Kepulauan Riau. Dengan tuajuan mengidentifikasi model partisipasi komunikasi pemerintahan dalam pengelolaan potensi objek wisata di Pulau Penyengat, serta mengkaji karakteristik masyarakat sehingga terlihat bentuk dan tingkat partisipasi masyarakat dalam pemeliharaan dan pelestarian lingkungan hidup dalam mendukung Desa Wisata di Pulau Penyengat.

\section{KERANGKA TEORI}

\section{Model Komunikasi Pemerintahan}

Secara umum komunikasi adalah proses interaksi dan simbolik sosial yang digunakan orang untuk menyusun nilainilai yang membentuk citra mengenai sesuatu hal berdasarkan itu bertindak dan untuk membentuk citra melalui simbolsimbol. Pengertian komunikasi pemerintahan adalah penyampaian ide, program, dan program pemerintah kepada masyarakat dalam rangka mencapai tujuan bernegara dan berbangsa. Sementara itu, pengertian model komunikasi pemerintahan merupakan deskripsi ideal mengenai apa yang dibutuhkan untuk terjadinya komunikasi di instansi atau pemerintahn. Model komunikasi pemerintahan mempresentasikan secara abstrak pentingnya komunikasi yang efektif dalam dunia nyata.

Disisi lain aparatur pemerintah paham dengan komunikasi namun tidak semuanya aparat memahami bagaimana berkomunikasi secara efektif, khususnya dalam rangka pelaksanaan program pemerintah, terkhusus untuk melakukan fungsi-fungsi utama yang mencakup pelayanan, pemberdayaan masyarakat dalam pengembangan wisata untuk 
NAKHODA:

JURNAL

ILMU PEMERINTAHAN
NAKHODA: JURNAL ILMU PEMERINTAHAN

Edisi Januari - Juni 2019 Volume: 18 Nomor: 1

ISSN : 1829-5827 | E-ISSN : 2656-5277

DOI : https://doi.org/10.35967/jipn

https://nakhoda.ejournal.unri.ac.id/index.php/JIPN mencapai kebahagiaan yang sebesarbesarnya tanpa merugikan pihak lain secara illegal.

Berdasarkan tugas dan posisinya dalam struktur pemerintah lebih cenderung bersifat memberitahu (telling) bukan mendengarkan (listening) informasi, sebaliknya bawahan menyampaikan informasi kepada atasan tentang apa yang mereka inginkan untuk didengar oleh pimpinannya, jadi perbedaan status antara pengirim (sender) dan penerima (receiver) dapat menjadi hambatan (nose) dalam proses komunikasi yang efektif.

Komunikasi

pemerintah mempunyai dampak atau pengaruh terhadap bentuk, sasaran (goal), tugas komunikasi pemerintah termasuk pemeliharaan relasi baik, tanpa atau adanya sarana dan prasarana untuk hubungan komunikasi dalam segala arah. kegiatan komunikasi pemerintah akan sulit diketahui apa yang sudah dicapai, apa yang akan pemerintah raih dan bagaimana kendala, sehingga sulit bagi organisasi untuk mengevaluasi pekerjaan khususnya bidang parwisata pulau penyengat Kepulauan Riau.

Komunikasi

pemerintahan merupakan sumber informasi bagi pimpinan dalam membuat berbagai kebijakan. jika informasi yang diperoleh tidak lengkap akan mengakibatkan pengambilan keputusann tidak efektif. Komunikasi antar pimpinan dan bawahan bukan saja sebagai alat untuk menyampaikan informasi tetapi juga sarana memadukan aktivitas kerjasama antar bidang.

Disisi lain, berkomunikasi itu kelihatannya mudah dan sederhana, tetapi sebenarnya tidak terlepas dari berbagai kendala atau hambatan dalam pelaksanaannya atau praktek komunikasi. Penting bagi pemerintah mengetahui atau menyadari adanya hambatan atau faktor lain bisa menjadi kendala dalam aktivitas berkomunikasi. Agar proses penyampaian pesan dalam komunikasi pemerintahan berlangsung dengan baik perlu saling pengertian atau kesepakatan bersama untuk mencapai tujuan.

\section{Partisipasi Masyarakat dalam Pengembangan Pariwista}

Partisipasi dapat disebut sebagai kekuatan yang dimiliki oleh masyarakat dalam mengatasi persoalan kehidupan yang lebih baik pada masa mendatang. Partisipasi merupakan redistribusi kekuatan, yang memungkinkan semua kaum ekonomi dan politik untuk dilibatkan dalam perencanaan pembangunan masa depan. Cohen dan Uphoff (1979) membagi partisipasi ke beberapa tahapan, yaitu perncanaan, pelaksanaan, dan evaluasi serta mengikmati..

Pertama, perencanaan, keikutsertaan masyarakat dalam rapatrapat formal. Perencanaan bertujuan untuk melihat sejauh mana kesadaran dan pertisipasi masyarakat dalam memberikan penilaian dan pemilihan sesuai dengan kebutuhan masyarakat itu sendiri. Pengambilan keputusan dilakukan oleh pimpinan (stakeholders) terpusat pada yang memiliki kekuasaan.

Kedua, pelaksanaan, merupakan tahap terpenting dalam pelaksanaan program atau pembangunan. Tahap pelaksanaan sering diartikan sebagai tahap implementasi dan pelaksnaan, tidak hanya bernilai sebuah tindakan nyata, namun dapat pula secara memberikan masukan 
perbaikan program melalui sumber daya manusia dan sumberdaya alam.

Tahap ini sangat berbeda dengan top down dan bottom up, namun partisipasi dapat berupa gabungan dari kedua diatas, yang bekerja bukanlah hanya pihak perusahaan, namun kemudian membangun hal yang diperlukan.

Dan ketiga, evaluasi, tahap ini merupakan umpan balik (feedback) yang dapat memberi masukan demi perbaikan pelaksanaan program atau kegiatan selanjutnya. Tahap ini merupakan kemampuan masyarakat dalam menilai baik, berhasil, dan efektif atau tidak suatu program. Evaluasi pada masyarakat setingkat lebih memahami kegunaan efektifitas dan kekurangan dari suatu program yang diberikan sehingga masyarakat bisa menyusun solusi atas program mereka.

Keempat, menikmati hasil, tahapan ini menjadi indikator atau faktor keberhasilan partisipasi masyarakat dalam perencanaan dan pelaksanaan program pariwisata. Dalam melihat posisi masyarakat sebagai subjek dan objek pembangunan pariwisata, semakin besar manfaat program dirasakan, agar mampu merasakan keberhasilan dari program yang dilaksanakan.

\section{Analisis SWOT}

Metode analisis SWOT merupakan identifikasi berbagai faktor secara sistematis dan menyeluruh dalam merumuskan beberapa strategi. Analisis SWOT didasarkan pada logika yang dapat memaksimalkan empat item adalah Strengths dan Opportunities, Weaknesses dan Threats. Dalam penelitian ini, digunakan untuk mengidentifikasi relasi- relasi sumberdaya ekowisata pulau penyengat dengan sumberdaya yang lain. Oleh itu semua pihak, khususnya masyarakat lokal, perlu mengetahui apa kekuatan dan kelemahan yang dimiliki oleh kawasan dan obyek ekowisata Pulau Penyengat kota Tanjung Pinang Kepulauan Riau.

Menurut Damanik (2006), agar hasil analisis SWOT berjalan dengan baik, sebaiknya dijelaskan dalam 3 kuadran:

$\begin{aligned} \text { Kuadran 1 : } & \text { pulau penyengat } \\ & \text { merupakan daerah sangat } \\ & \text { menguntungkan karena } \\ & \text { memiliki peluang seperti } \\ & \text { geografis sehingga dapat } \\ & \text { memanfaatkan peluang } \\ & \text { yang ada Komunikasi } \\ & \text { pemerintahan yang harus } \\ & \text { diterapkan dalam kondisi } \\ & \text { ini adalah mendukung } \\ & \text { kebijakan pertumbuhan } \\ & \text { yang agresif (growth } \\ & \text { oriented strategy) }\end{aligned}$

Kuadran 2: kekurangan/ancaman yang ada tetapi disisi lain terdapat kekuatan internal. Strategi penembangan pulau penyengat tidak terlepas dari faktor kekuatan dalam memanfaatkan peluang jangka panjang atau yang disebut dengan strategi diversifikasi pasar.

Kuadran 3: rencana pengembangan wisata penyengat mempunyai peluang yang sangat besar tetapi di lain pihak, rencana tersebut 
NAKHODA:

JURNAL

ILMU PEMERINTAHAN
NAKHODA: JURNAL ILMU PEMERINTAHAN

Edisi Januari - Juni 2019 Volume: 18 Nomor: 1

ISSN : 1829-5827 | E-ISSN : 2656-5277

DOI : https://doi.org/10.35967/jipn

https://nakhoda.ejournal.unri.ac.id/index.php/JIPN terdapat beberapa

kekurangan internal.

Fokus strategi yang harus

dilakukan adalah meninjau

ulang (turn around)

masalah-masalah internal

sehingga permasalahan

tersebut dapat

diminimalkan.

Kuadran 4: Rencana pengembangan ekowisata tersebut menghadapi berbagai ancaman pengembangan wisata pulau penyengat dari internal. Strategi yang dilakukan adalah defensif (bertahan).

\section{METODE PENELITIAN}

Metode penelitian yang digunakan adalah pendekatan kualitatif dan kuantitatif (mix method) dimana data yang dikumpul berupa tanggapan, informasi pualu penyengat, konsep-konsep dan keterangan yang berbentuk uraian dalam mengungkapkan masalah seputar pariwisata penyngat. Penerapan mix method dalam penelitian ini mengguna tanya jawab berupa pertanyaan dalam rumusan masalah sebagaimana diuraikan dalam pendahuluan. Dengan demikian, penelitian akan berisi kutipan data lapangan untuk memberi gambaran penyajian penelitian ini. Data tersebut berasal dari naskah wawancara, kuisioner, catatan lapangan, dokumen, dan dokumen resmi lainnya.

Penelitian ini dilaksanakan di Pulau Penyengat Kepulauan Riau. Alasan pemilihan Pulau Penyengat sebagai objek penelitian adalah; a) potensi (alam, pusaka), b) partisipasi masyarakat, c) kebijakan/regulasi, dan d) strategi pengembangan kawasan wisata Pulau Penyengat berdasarkan kondisi objektif tersebut.

Dalam Penelitian ini, secara garis besar proses pengumpulan data menggunakan metoda pokok yang saling berkaitan dan melengkapi, yaitu menggunakan Interview, Kuisioner, Observasi dan Penelusuran dokumen

\section{HASIL DAN PEMBAHASAN}

\section{Model Komunikasi Pemerintah Dalam Mendukung Pengembangan wisata Pulau Penyengat \\ Komunikasi pemerintahan harus} mampu menempatkan semua pihak sebagai partisipan dalam urusan pemerintahan kota Kota Tanjung Pinang atau setara sehingga tidak ada dominasi dalam arus informasi dari salah satu pihak. Komunikasi permerintahan yang partisipatif harus menghasilkan keputusan secara demokratis melalui proses interaksi dan transaksi secara terus-menerus sehingga konsensus dapat dipertahankan.

Komunikasi antar lembaga harus berlangsung dalam suasana dialogis dan terbuka tanpa tekanan, dan setiap yang terlibat mengambil manfaat sesuai kontribusinya secara adil serta bijaksana. Analisis dari pertanyaan tentang partisipasi masyarakat dalam mendukung pengembangan wisata Pulau Penyengat kepulauan Riau. Model frekuensi adalah sebagai langkah awal analisis dilakukan dengan melakukan pengelompokan responden berdasarkan kategori umur, jenis kelamin, pendidikan dan pekerjaan. Selanjutnya analisis dilakukan berdasarkan variabel respons dan partisipasi masyarakat 
NAKHODA:

JURNAL

ILMU PEMERINTAHAN
NAKHODA: JURNAL ILMU PEMERINTAHAN

Edisi Januari - Juni 2019 Volume: 18 Nomor: 1

ISSN : 1829-5827 | E-ISSN : 2656-5277

DOI : https://doi.org/10.35967/jipn

https://nakhoda.ejournal.unri.ac.id/index.php/JIPN dalam pengembangan wisata pulau penyengat.

\section{Identifkasi Responden}

Adapun identifikasi responden tergambar dalam penjelasan berikut; a) Identifikasi Responden

Tabel berikut menggambarkan identifikasi responden dalam penelitian ini

Tabel 1. Identifikasi Responden

\begin{tabular}{|c|c|c|c|}
\hline No & Profil Responden & Jumlah & Persentase \\
\hline I & Jenis Kelamin & $\mathbf{( 1 4 5 )}$ & $\mathbf{( 1 0 0 \% )}$ \\
\hline 1 & Pria & 96 & 62,58 \\
2 & Wanita & 50 & 37,42 \\
\hline II & Kelompok Umur & $\mathbf{( 1 5 5 )}$ & $\mathbf{( 1 0 0 \% )}$ \\
\hline 1 & $<$ dari 20 tahun & 27 & 17,4 \\
\hline 2 & $20-29$ Tahun & 35 & 22,58 \\
\hline 3 & $30-39$ Tahun & 46 & 29,67 \\
\hline 4 & $40-49$ Tahun & 30 & 19,35 \\
\hline 5 & 49 Tahun $>$ & 17 & 11 \\
\hline III & Tingkat Pendidikan & $\mathbf{( 1 5 4 )}$ & $\mathbf{( 1 0 0 \% )}$ \\
\hline 1 & SLTP & 79 Orang & 29 \\
2 & SLTA & 45 Orang & 15 \\
3 & D3 & 24 Orang & 5 \\
4 & S1 & 5 Orang & $(\mathbf{1 0 0 \% )}$ \\
\hline IV & Jenis Pekerjaan & $(\mathbf{1 4 5 )}$ & 14,8 \\
\hline 1 & Penarik Becak & 23 Orang & 29 \\
2 & Nelayan & 45 Orang & 15,4 \\
& Buruh & 24 Orang & 8 \\
\hline 3 & Pedagang & 13 Orang & 22,5 \\
4 & & 25 Orang & 9,8 \\
\hline 5 & Pegawai Swasta & 15 Orang & \\
\hline 6 & Pegawai Pemerintah & & \\
\hline
\end{tabular}

Sumber: Olahan Penelitian

Sebaran responden pada kelompok umur yang cukup merata memperkuat basis analisis respon publik dalam pengembangan wisata di Pulau Penyengat Kota Tanjungpinang. Tidak dapat dipungkiri bahwa faktor umur mempengaruhi keberlangsungan informasi sejarah Pulau Penyengat termasuk pemahaman mengenai latar sosio kultural masyarakat Pulau Penyengat. Diakui bahwa keberlangsungan informasi sejarah dari masa ke masa bergantung pada warisan informasi turun temurun masyarakat Pulau Penyengat yang sampai saat ini belum begitu detail dikemas oleh Pemerintah Daerah. Suatu program pemerintah yang berkaitan dengan aspek sosial, ekonomi, dan budaya masyarakat 
NAKHODA:

JURNAL

ILMU PEMERINTAHAN
NAKHODA: JURNAL ILMU PEMERINTAHAN

Edisi Januari - Juni 2019 Volume: 18 Nomor: 1

ISSN : 1829-5827 | E-ISSN : 2656-5277

DOI : https://doi.org/10.35967/jipn

https://nakhoda.ejournal.unri.ac.id/index.php/JIPN tidak akan berhasil tanpa peran aktif partisipasi komunikasi pemerintah, baik kedudukannya sebagai obyek maupun subyek dalam pengembangan pariwisata.

Tabel 2. Nama Situs Cagar Budaya dan SK Penetapan Sebagai Situs Cagar Budaya di Pulau Penyengat

\begin{tabular}{|c|c|c|}
\hline No. & Nama situs & Keterangan \\
\hline 1. & $\begin{array}{l}\text { Mesjid Raya Sultan Riau Pulau } \\
\text { Penyengat }\end{array}$ & $\begin{array}{l}\text { Keputusan Menteri Kebudayaan dan } \\
\text { Pariwisata Republik Indonesia } \\
\text { Nomor } 9 \text { tahun } 2003\end{array}$ \\
\hline 2. & Makam Engku Putri & $\begin{array}{l}\text { Kepmen Kebudayaan dan Pariwisata } \\
\text { No KM 14/PW.007/KKP/2004 }\end{array}$ \\
\hline 3. & Makam Raja Haji Fisabilillah & $\begin{array}{l}\text { Kepmen Kebudayaan dan Pariwisata } \\
\text { No KM 14/PW.007/KKP/2004 }\end{array}$ \\
\hline 4. & $\begin{array}{l}\text { Perpustakaan Kuno Khutub } \\
\text { Khana Yamtuan Ahmady }\end{array}$ & \\
\hline 5. & $\begin{array}{l}\text { Bekas Gedung Engku Haji Daud } \\
\text { (Tabib Kerajaan) }\end{array}$ & \\
\hline 6. & $\begin{array}{l}\text { Bekas Istana Sultan Abdul } \\
\text { Rahman Muazam Syah }\end{array}$ & \\
\hline 7. & Komplek Makam Raja Ja’afar & $\begin{array}{l}\text { Kepmen Kebudayaan dan Pariwisata } \\
\text { No KM 14/PW.007/KKP/2004 }\end{array}$ \\
\hline 8. & Bekas Gedung Tengku Bilik & $\begin{array}{l}\text { Kepmen Kebudayaan dan Pariwisata } \\
\text { No KM 14/PW.007/KKP/2004 }\end{array}$ \\
\hline 9. & $\begin{array}{l}\text { Bekas Istana Raja Ali Marhum } \\
\text { Kantor }\end{array}$ & $\begin{array}{l}\text { Kepmen Kebudayaan dan Pariwisata } \\
\text { No KM 14/PW.007/KKP/2004 }\end{array}$ \\
\hline 10. & $\begin{array}{l}\text { Istana Bahjah (Istana Raja Ali } \\
\text { Kelana) }\end{array}$ & \\
\hline 11. & $\begin{array}{l}\text { Makam Yang Dipertuan Muda ke } \\
\text { VII }\end{array}$ & $\begin{array}{l}\text { Kepmen Kebudayaan dan Pariwisata } \\
\text { No KM 14/PW.007/KKP/2004 }\end{array}$ \\
\hline 12. & Makam Embung Fatimah & \\
\hline 13. & $\begin{array}{l}\text { Gedung Mesiu atau Gedung Obat } \\
\text { Bedil }\end{array}$ & $\begin{array}{l}\text { Kepmen Kebudayaan dan Pariwisata } \\
\text { No. } 9 \text { tahun } 2003\end{array}$ \\
\hline 14. & $\begin{array}{l}\text { Kubu (Benteng) dan Parit-Parit } \\
\text { Pertahanan }\end{array}$ & $\begin{array}{l}\text { Kepmen Kebudayaan dan Pariwisata } \\
\text { No KM 14/PW.007/KKP/2004 }\end{array}$ \\
\hline 15. & $\begin{array}{l}\text { Bekas Gedung Rusydiah Klab dan } \\
\text { Percetakan Kerajaan }\end{array}$ & \\
\hline 16. & $\begin{array}{l}\text { Gedung Raja Haji Abdullah } \\
\text { (Hakim Kerajaan) }\end{array}$ & \\
\hline 17. & Perigi Puteri (Perigi Kunci) & $\begin{array}{l}\text { Kepmen Kebudayaan dan Pariwisata } \\
\text { No KM 14/PW.007/KKP/2004 }\end{array}$ \\
\hline
\end{tabular}

Sumber: Data Olahan Penelitian 
NAKHODA:

JURNAL

ILMU PEMERINTAHAN
NAKHODA: JURNAL ILMU PEMERINTAHAN

Edisi Januari - Juni 2019 Volume: 18 Nomor: 1

ISSN : 1829-5827 | E-ISSN : 2656-5277

DOI : https://doi.org/10.35967/jipn

https://nakhoda.ejournal.unri.ac.id/index.php/JIPN
Berdasarkan pemaparan di atas, destinasi wisata pusaka (cagar budaya) Penyengat tepat untuk dijadikan sebagai kawasan Desa Wisata berbasis wisata Pusaka. Pariwisata pusaka di Pulau Penyengat, seperti halnya di tempat lain di Indonesia, merupakan fenomena baru yang umumnya berkembang di awal milenium. Perkembangannya secara umum bukan merupakan hasil daripada perencanaan yang disengaja dan matang, namun lebih bersifat sporadis oleh komunitaskomunitas atau organisasi-organisasi tertentu. Komunitas atau organisasi ini pada umumnya digagasi dan dimotori oleh para peminat pusaka di kota-kota besar di Indonesia dan bersifat nirlaba.

Selain itu, terutama bagi pemerintah, kendala klasik tetap menjadi tantangan dalam perencanaan dan pengembangan. Keterbatasan finansial dan sumber daya manusia yang kompeten di bidang 'pariwisata pusaka' masih dihadapi. Pemerintah masih mengambil sikap hatihati dalam bertindak, serta mengatur skala prioritas terhadap perencanaan dan pengembangan sumber daya pariwisata yang dianggap dan terbukti telah lebih menjanjikan dalam hal menghasilkan pendapatan bagi daerah.

Perencanaan kepariwisataan tidak dapat dilepaskan dari unsur pemangku kepentingan (stakeholders) dan kepentingannya masing-masing. Pemangku kepentingan dalam perencanaan kepariwisataan mencakup wisatawan, penduduk lokal, industri pariwisata, dan agen-agen pemerintah (baik lokal, regional, nasional, dan internasional).
Tabel 3. Respon Masyarakat Terkait Manajemen pengelolah Pulau Penyengat

\begin{tabular}{|c|l|c|c|c|}
\hline No & $\begin{array}{l}\text { Manajemen } \\
\text { Pengunjung }\end{array}$ & $\begin{array}{c}\text { Setuju } \\
(\%)\end{array}$ & $\begin{array}{c}\text { Tidak } \\
\text { Setuju } \\
(\%)\end{array}$ & $\begin{array}{c}\text { Total } \\
(\%)\end{array}$ \\
\hline 1 & $\begin{array}{l}\text { Swadaya } \\
\text { Masyarakat }\end{array}$ & 68 & 87 & 155 \\
$(49 \%)$ & $(51 \%)$ & $(100 \%)$ \\
\hline 2 & $\begin{array}{l}\text { Dorongan } \\
\text { Pemerintah }\end{array}$ & $\begin{array}{c}101 \\
(70 \%)\end{array}$ & $\begin{array}{c}54 \\
(50 \%)\end{array}$ & $\begin{array}{c}155 \\
(100 \%)\end{array}$ \\
\hline 3 & $\begin{array}{l}\text { Inisiatif } \\
\text { Swasta }\end{array}$ & 90 & 65 & 155 \\
$(60 \%)$ & $(40 \%)$ & $(100 \%)$ \\
\hline
\end{tabular}

Sumber: Data Olahan Penelitian

Pengelolaan dalam pengembangan kawasan wisata wisata menjadi modal dalam industri pariwisata. Pengelolaan (manajemen) pengunjung ini berkaitan dengan ketepatan arus informasi (baik transportasi maupun akomodasi) pariwisata. Dalam hal pengembangan kawasan wisata Pulau Penyengat secara khusus belum ditemukan pengelolaan pengunjung baik yang ditawarkan oleh pegiat maupun inisiatif masyarakat. Padahal aspek pengelolaan pengunjung ini sangat penting karena menyajikan kepastian harga, objek wisata dan hal-hal yang didapat wisawatan dalam melakukan kunjungan wisata. Masyarakat Pulau Penyengat merespon positif untuk pengelolaan wisatawan, namun dengan lebih banyak dorongan pemerintah dalam artian bahwa pemerintah mesti bergiyat menyusun program dalam pengelolaan pengunjung ini agar masyarakat dapat berdaya mengelola wisatawan. 
NAKHODA:

JURNAL

ILMU PEMERINTAHAN
NAKHODA: JURNAL ILMU PEMERINTAHAN

Edisi Januari - Juni 2019 Volume: 18 Nomor: 1

ISSN : 1829-5827 | E-ISSN : 2656-5277

DOI : https://doi.org/10.35967/jipn

https://nakhoda.ejournal.unri.ac.id/index.php/JIPN

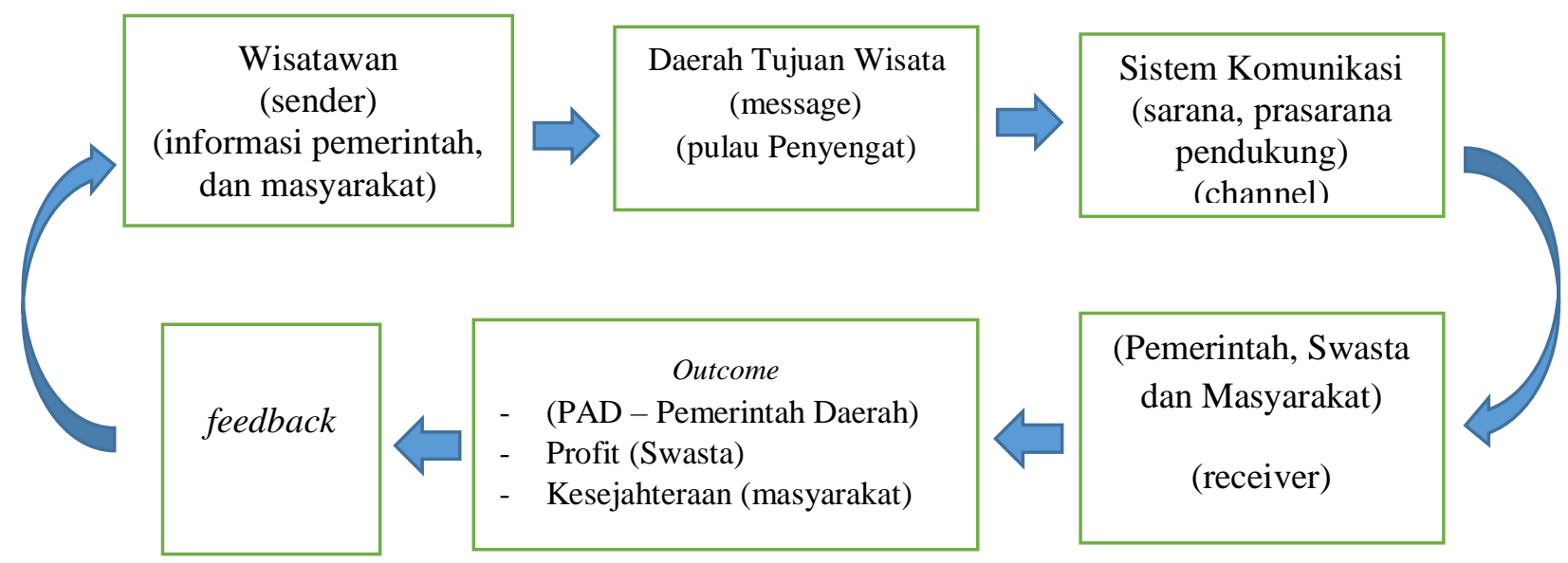

Diagram 1. Model Komunikasi Pemerintahan dalam pengembangan Pariwisata Pulau Penyengat.

\section{Sistem Transportasi komunikasi dalam Pariwisata Pulau Penyengat.}

Pengembangan kawasan wisata tidak akan berjalan optimal tanpa keterpaduan sistem transportasi (Informasi Rute dan Jadwal, ICT, Akses Reservasi Moda Transportasi) pariwisata. Keberadaan sistem transportasi menjadi acuan wisatawan dalam menetapkan tujuan wisata, pada sistem transportasi ini dijelaskan secara rinci besaran harga dan perkiraan biaya yang dikeluarkan oleh wisatawan ketika melakukan kunjungan wisata. Pengembangan wisata Pulau Penyengat belum optimalnya terutama bila dikaitkan dengan Pulau Penyengat sebagai destinasi tujuan wisata unggulan di Kepulauan Riau disebabkan belum dikemasnya sistem transportasi secara terpadu. Menanggapi hal itu, mayoritas masyarakat Pulau Penyengat menyatakan setuju untuk dilakukan pengembangan sistem transportasi pariwisata di Pulau Penyengat.
Tabel 4. Respon Masyarakat Transportasi Wisata di Pulau Penyengat

\begin{tabular}{|c|l|c|c|c|}
\hline No & $\begin{array}{l}\text { Sistem } \\
\text { Transportasi } \\
\text { Wisata }\end{array}$ & $\begin{array}{c}\text { Setuju } \\
(\%)\end{array}$ & $\begin{array}{c}\text { Tidak } \\
\text { Setuju } \\
(\%)\end{array}$ & $\begin{array}{c}\text { Total } \\
(\%)\end{array}$ \\
\hline 1 & $\begin{array}{l}\text { Informasi } \\
\text { Rute dan } \\
\text { Jadwal }\end{array}$ & $\begin{array}{c}160 \\
(97 \%)\end{array}$ & $5(3 \%)$ & $\begin{array}{c}155 \\
(100 \%)\end{array}$ \\
\hline 2 & ICT & $\begin{array}{c}135 \\
(87 \%)\end{array}$ & $\begin{array}{c}22 \\
(13 \%)\end{array}$ & $\begin{array}{c}155 \\
(100 \%)\end{array}$ \\
\hline 3 & $\begin{array}{l}\text { Akses } \\
\text { Reservasi } \\
\text { Wisata }\end{array}$ & $\begin{array}{c}120 \\
(83 \%)\end{array}$ & $\begin{array}{c}27 \\
(17 \%)\end{array}$ & $\begin{array}{c}155 \\
(100 \%)\end{array}$ \\
\hline
\end{tabular}

Sumber: Data Olahan Penelitian 2018

Belum terpadunya sistem transportasi yang baik menyebabkan wisatawan kesulitan dalam menentukan besaran biaya yang akan dikeluarkan dalam melakukan kunjungan wisata ke Pulau Penyengat. Tourism Board Kota Tanjungpinang juga tidak menjelaskan secara rinci sistem transportasi yang dimaksud sehingga wisatawan yang datang ke Pulau Penyengat memperoleh informasi tidak akurat. Selain itu, kelompok pegiat wisata 
NAKHODA:

JURNAL

ILMU PEMERINTAHAN
NAKHODA: JURNAL ILMU PEMERINTAHAN

Edisi Januari - Juni 2019 Volume: 18 Nomor: 1

ISSN : 1829-5827 | E-ISSN : 2656-5277

DOI : https://doi.org/10.35967/jipn

https://nakhoda.ejournal.unri.ac.id/index.php/JIPN juga belum menggeliat dalam mengembangkan pariwisata di Pulau Penyengat misalnya dengan menyajikan rangkaian tour and traveling ke Pulau Penyengat

\section{Partisipasi pemerintah dan masyarakat dalam SWOT}

Strategi pengembangan kawasan wisata Pulau Penyengat diarahkan berdasarkan Analisis SWOT. Analisis SWOT (strengths, weaknesses, opportunities, threats) merupakan suatu metode analisis yang akan menggambarkan kekuatan, kelemahan, peluang, dan ancaman, serta kendalakendala yang harus dihadapi dalam suatu proses perencanaan. Dengan mengetahui kekuatan dan kelemahan, akan mampu dikurangi kelemahan yang ada dan pada saat yang sama memaksimalkan kekuatan. Hal yang sama juga berlaku pada tantangan dan peluang, dimana pada saat tantangan dapat diperkecil, peluang yang ada justru diperbesar. Berikut akan diuraikan analisis terhadap kondisi yang dihadapi dalam mengembangkan pariwisata di Pulau Penyengat yang meliputi analisis kondisi internal dan analisis kondisi eksternal.

Pariwisata dipersepsikan masyarakat sebagai wahana untuk meningkatkan kesejahtaraan, terutama meningkatkan pendapatan income pemerintah, khususnya pendapatan devisa bagi negara. Perkembangan pariwisata lebih bersifat ekonomi-sentris dan berorientasi pada pertumbuhan perkapital. Jumlah pendapatan seuatu devisa ditentukan oleh jumlah kunjungan wisatawan, dan lama kunjungan wisatawan ke negara tujuan destinasi wisata pulau penyengat, maka tolok ukur keberhasilan pengembangan pariwisata pulau penyengat:

a. Jumlah kunjungan wisatawan domestik dan internasional

b. Pengeluaran biaya wisatawan(expenditures)

c. waktu tinggal wisatawan(lengh of stay) di Pulau Penyengat.

Dalam pengembangan kepariwisataan wisata pulau penyengat, objek wisata (masjid, dan makam) merupakan unsur vital sekaligus penggerak utama bagi wisatawan dalam memutuskan perjalanan dan kunjungan ke suatu daerah tanjung pinang.

Pengembangan destinasi pariwisata pulau penyengat memiliki keterkaitan lintas sektor yang mampu membuka peluang investasi sangat luas bagi masyarakat dan pemerintah Tanjung Pinang. Maka dampak ekonomi yang ditimbulkan pariwisata pulau penyengat diharapkan berdimensi di multi sektor, yaitu ekonomi, sosial dan budaya. Dampak lain dalam bidang ekonomi adalah berupa pertumbuhan industri atau usaha yang terkait dengan pariwisata di Pulau Penyengat. Bentuk kegiatan wisata alternatif perlu menjadi perhatian penting pemerintah daerah Tanjung Pinang dalam pengembangan daya tarik wisata, khususnya terkait dengan keragaman budaya dan keunikan alam.

Melalui pengembangan wisata, maka suatu destinasi pariwisata akan memiliki keragaman atau diversifikasi produk lokal yang akan membuka peluang kunjungan ulang bagi wisatawan yang pernah berkunjung ke daerah atau destinasi Pulau Penyengat. Pengembangan wisata lain seperti wisata atau desa wisata juga 
NAKHODA: JURNAL ILMU PEMERINTAHAN 
